Russian Academy of Sciences, Far Eastern Branch

Botanical Garden-Institute

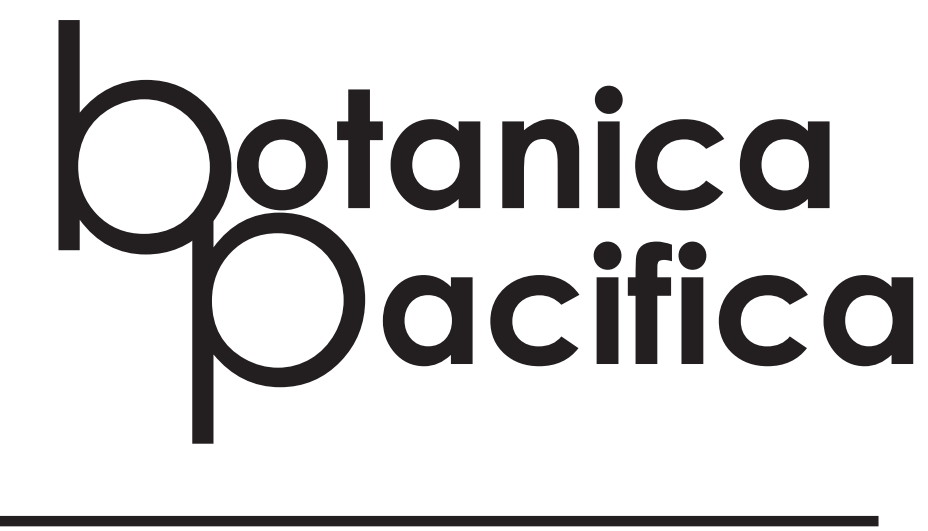

A JOURNAL OF PLANT SCIENCE
AND CONSERVATION

VOLUME 9, NO. 12020 


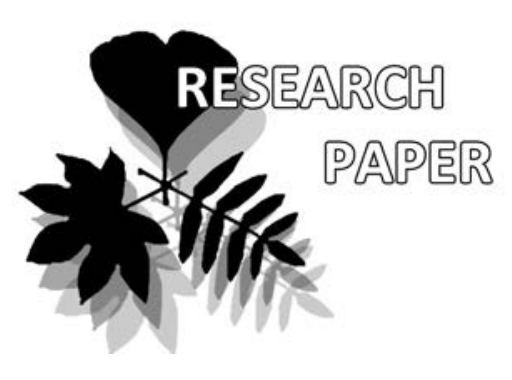

Elena V. Andysheva ${ }^{1 *}$

e-mail: lenok-luchik@mail.ru

Elena P. Khramova ${ }^{2}$

e-mail:khramova@ngs.ru

${ }^{1}$ Amur Branch of the

Botanical Garden-Institute FEB RAS,

Blagoveshchensk, Russia

${ }^{2}$ Central Siberian Botanical Garden

SB RAS, Novosibirsk, Russia

Manuscript received: 28.07.2019

Review completed: 15.12.2019

Accepted for publication: 15.02 .2020

Published online: 26.02 .2020

\section{A chemotaxonomic study of phenolic compounds in the species of the genus Dasiphora (Rosaceae) from the Russian Far East and Eastern Siberia}

\author{
Elena V. Andysheva ${ }^{1 *}$, Elena P. Khramova ${ }^{2}$
}

\begin{abstract}
A B S T R A C T
The profile and concentrations of phenolic compounds were determined in the leaves of five species and one variety of the genus Dasiphora Raf. from natural habitats of the Russian Far East and Eastern Siberia. It was found that the phenolic profile is specific for each taxon under study. The largest number of phenolic components was detected in D. davurica and D. mandshurica, and the lowest in $D$. parvifolia and $D$. davurica var. flava. For each studied taxon, a distinct set of highly accumulated phenolic components was identified. According to paired-affinity and group affinity calculations, species $D$. mandshurica and $D$. davurica are the closest relatives. Species specificity was evaluated on the basis of aglycon structure of flavonol glycosides. $D$. fruticosa, D. parvifolia, and $D$. davurica showed a tendency of increased accumulation of quercetin glycosides, whereas $D$. davurica var. flava, D. gorovoii, and D. mandshurica mainly accumulate the glycosides of rhamnetin. D. parvifolia and $D$. gorovoii are characterized by the highest content of phenolic compounds (in total and by groups), whereas $D$. davurica is distinguished by the high content of ellagic compounds.
\end{abstract}

Ke y word s : Dasiphora, Russian Far East, Eastern Siberia, chemotaxonomic markers, phenolic compounds

\section{P E 3 Ю M E}

Андышева Е.В., Храмова Е.П. Хемотаксономический анализ фенольных соединений представителей рода Dasiphora (Rosaceae) российского Аальнего Востока и Восточной Сибири. Приведены результаты исследования состава и содержания фенольных соединений в Аистьях растений пяти видов и одной разновидности рода Dasiphora Raf. Установлено, что Аля кажАого исследованного виАа характерен свой фенольный профиль. Наибольшее число компонентов фенольной структуры присутствовало у растений $D$. davurica и $D$. mandshurica, наименьшее - у D. parvifolia и D. davurica var. flava. Аیя каждого исследованного вида установлено повышенное накопление определенного набора компонентов. По коэффициентам парного и группового сходства наиболее близки виды D. mandshurica и D. davurica. Отмечена виАоспецифичность в зависимости от агликоновой структуры флавонолгликозилов. D. fruticosa, $D$. parvifolia и $D$. davurica свойственно повышенное накопление гликозидов кверцетина, D. davurica var. flava, D. gorovoï и D. mandshurica - гликозидов рамнетина. По наибольшему содержанию фенольных соединений (суммарному и по группам) выделены виды D. parvifolia и $D$. gorovoii, по суммарному содержанию эльаговых соединений - D. davurica.

КАючевые слова: род Dasiphora, фенольные соединения, хемотаксономия, российский Аальний Восток, Восточная Сибирь
Genus Dasiphora Raf. (三 Pentaphylloides Hill) belongs to the family Rosaceae Juss. In the Asian part of Russia, there are five species and one variety: D. fruticosa (L.) Rydb., D. parvifolia (Fisch. ex Lehm.) Juz., D. mandshurica (Maxim.) Juz., D. davurica (Nestler) Kom. (Wolf 1908, Cherepanov 1995, Baikov 2012, IPNI 2015), D. gorovoii Pshennikova, and $D$. davurica var. flava (Vorosch.) Gorovoj, Pshenn. et S. Volkova (Pshennikova 2006, 2016, Baikov 2012).

Despite the low species diversity of the genus, the problems of its classification are still unsolved. The taxonomic details of the genus are always specified due to the revision of the number of affiliated species. Chemical methods may be used in addition to the classical methods of systematics to resolve its classification.
Phenolic compounds are valuable chemotaxonomic markers and may be utilized in systematics to resolve disputes and determine phylogenetic connections among taxa (Harborne 1977, Julkunen-Tiitto et al. 1996, Robards \& Antonovich 1997, Laitinen 2003, Williams et al. 2003, Wink 2003, Vysochina 2004, Raucher 2006).

The research on flavonol aglycones of the genus Potentilla showed species specificity of their biochemical profile and the suitability of their use for more accurate determination of taxonomic affiliations of these plants on different levels (Bate-Smith 1961), as confirmed later by 'Tril' (1977). Among the Siberian species of the genus Dasiphora, the differences in the concentrations and profile of phenolic compounds were found by Khramova (2013). 
This paper focus on comparison of the phenolic compositions within the genus Dasiphora across the large part of the eastern Asian Russia, to find species with high phenolic content, and to test if the phenolic composition can serve as chemotaxonomic markers.

\section{MATERIAL AND METHODS}

The materials for this chemotaxonomic study were specimens (leaves) of five species and of one variety of the genus Dasiphora from 62 coenotic populations (CPs) of the Russian Far East and Eastern Siberia. D. fruticosa specimens were collected in 52 geographically remote habitats: two in the Magadan Region (CPs 1 and 2), seven in the Sakha Republic (Yakutia) (CPs 3-9), two in the Irkutsk region (CPs 10 and 11), four in the Republic of Buryatia (CPs 12-15), five in the Zabaykalsky Territory (CPs 17-20), 20 in the Amur region (CPs 22-41), two in the Jewish Autonomous region (CPs 42 and 43), five in the Khabarovsk Territory (CPs $44-48$ ), four on the Kuril Islands (CPs 60-62), one specimen in the Primorsky Territory (CP 49), and one on the Sakhalin Island (CP 59). D. davurica specimens were collected in four (CPs 50-53) and D. mandshurica specimens in three natural populations (CPs 56-58). The specimens of D. gorovoii (CP 55) and D. davurica var. flava (CP 54) were represented by a single population each from the Primorsky Territory. The single population of $D$. parvifolia (CP 16) is located in the Republic of Buryatia (Fig. 1).

To identify and quantify phenolic compounds (total content, by groups, and individual components), a sample from 30 individual plants on average was taken in the mass blooming phase. Annual shoots 15-20 cm long with leaves were cut off evenly across the crown, and the leaves were separated and air dried completely. Aqueous ethanol extracts of the vegetation samples were prepared according to the method described by Ermakov et al. (1987). Then, to rid the extracts of hydrophilic impurities, the solidphase extraction method was used (Sychyov 2005). The detailed description of sample preparation may be found in the study by Khramova et al. (2013). The analysis of the profile and concentrations of phenolic compounds in the samples under study was carried out by high-performance liquid chromatography (HPLC) on an Agilent 1200 liquid chromatograph (Agilent Technologies, USA) with a diodematrix detector, an autosampler, and the chromatography data processing software ChemStation by the method of van Beek (2002) with a modification by Khramova (2014). The chromatographic separation was conducted at $26^{\circ} \mathrm{C}$ on a Zorbax SB-C18 Column $(4.6 \times 150 \mathrm{~mm}, 5 \mu \mathrm{m}$ internal diameter) with the Agilent Guard Column Hardware Kit. Isocratic elution in a methanol $-0.1 \%$ aqueous orthophosphoric acid $\left(\mathrm{H}_{3} \mathrm{PO}_{4}\right)$ system (31:69) lasted for $27 \mathrm{~min}$. The chromatographic analysis was performed in gradient elution mode. In the mobile phase (methanol plus the $0.1 \%$ aqueous solution of $\mathrm{H}_{3} \mathrm{PO}_{4}$ ), the proportion of methanol was changed from $33 \%$ to $46 \%$ during $11 \mathrm{~min}$, then from $46 \%$ to $56 \%$ during the next $12 \mathrm{~min}$, and from $56 \%$ to $100 \%$ during the next $4 \mathrm{~min}$. The flow rate was set to $1 \mathrm{ml} /$ min. The sample injection volume was $5 \mu \mathrm{l}$, and the analytical wavelengths were 254, 270, 290, 340, 360 and $370 \mathrm{~nm}$. The total content of phenolic compounds was calculated as the sum of chromatographic peak areas at $\lambda=360 \mathrm{~nm}$, because for many most active flavonoids, the maxima of absorption are in the long-wavelength area $(362 \pm 14 \mathrm{~nm})$, which allows us to distinguish them easily from other classes of plant substances. The total content of tannins was calculated by summing up the concentrations of ellagic acid and of its glycoside. Because of the absence of available standard samples and complicated conditions for separation of flavonol glycosides (quercetin, kaempferol, and rhamnetin glycosides were isolated separately) from the leaf extracts by the HPLC method, the analysis of free aglycones was carried out instead. Free aglycones were produced by the acid hydrolysis of the corresponding glycosides with subsequent recalculation (van Beek 2002, Yuriev et al. 2003). The chromatographic analysis was performed in gradient elution mode. In the mobile phase (methanol plus the $0.1 \%$ aqueous solution of $\mathrm{H}_{3} \mathrm{PO}_{4}$ ), the proportion of methanol was changed from $45 \%$ to $48 \%$ during $18 \mathrm{~min}$. For recalculation of aglycone concentration in a corresponding glycoside, some coefficients from literary data were employed: 2.504 for quercetin and 2.588 for kaempferol (van Beek 2002, Yuriev et al. 2003). The recalculation of rhamnetin concentration was done likewise for quercetin.

All the data were processed in Excel 7.0 and Statistica 10.0 software. For species D. fruticosa, D. davurica, and D. mandshurica, the means and standard deviations were calculated for all the specimens of the selected populations. For taxa D. parvifolia, D. davurica var. Alava, and D. gorovoii, which are represented by a single population each, the standard deviations were calculated to evaluate reproducibility of the measurements. The relative standard deviation of repetition (or reproducibility of the measurements) in the phenoliccompound analysis was $\sigma=0.011$.

Based on chromatographic data, the coefficients of paired affinity (PA)

and group affinity (GA)

$$
\mathrm{PA}=\frac{\text { spots in common for species } 1 \text { and } 2}{\text { total spots in } 1+2} \times 100
$$

$$
\mathrm{GA}=\Sigma \mathrm{PA}+100
$$

(Ellison et al. 1962, Suresh \& Pandey 2003) were calculated.

To determine the similarity in the aglycone content of hydrolysates of leaf extracts, cluster analysis of the plants was conducted by Ward's method. Euclidean distance was calculated as a measure of variation.

\section{RESULTS AND DISCUSSION}

Quantitation of phenolic content showed that in the leaf extracts of the species under study, the concentration of at least 34 compounds was determined successfully (Table 1). Based on the spectral data (ultraviolet spectrophotometry and mass spectrometry), a comparison of the substances' peak retention times with those of the standard samples and with literary data (Khramova \& Shkel 1999, Miliauskas et al. 2004, Khramova 2016) detected seven flavonol glycosides (hyperoside, isoquercitrin, rutin, avicularin, quercetrin, astragalin, 
and kaempferol-3-O-rutinoside), three aglycones (quercetin, kaempferol, and rhamnetin), and two ellagic compounds (ellagic acid and its glycoside). The rest of the compounds $(1-4,10,12,16-21$, 23-28, 30-33) were not identified, but during the chromatography run in "on-line" mode, their ultraviolet spectra were registered. For the unidentified compounds, absorption in the ultraviolet-visible region was typical; at the same time, the absorption spectrum contained two bands: one of them in a shorter-wave region (250-290 nm: band II), and the other in a longer-wave region (340-380 nm: band I). According to these data, all these leaf extract components belong to the flavonol family (Khramova 2016).

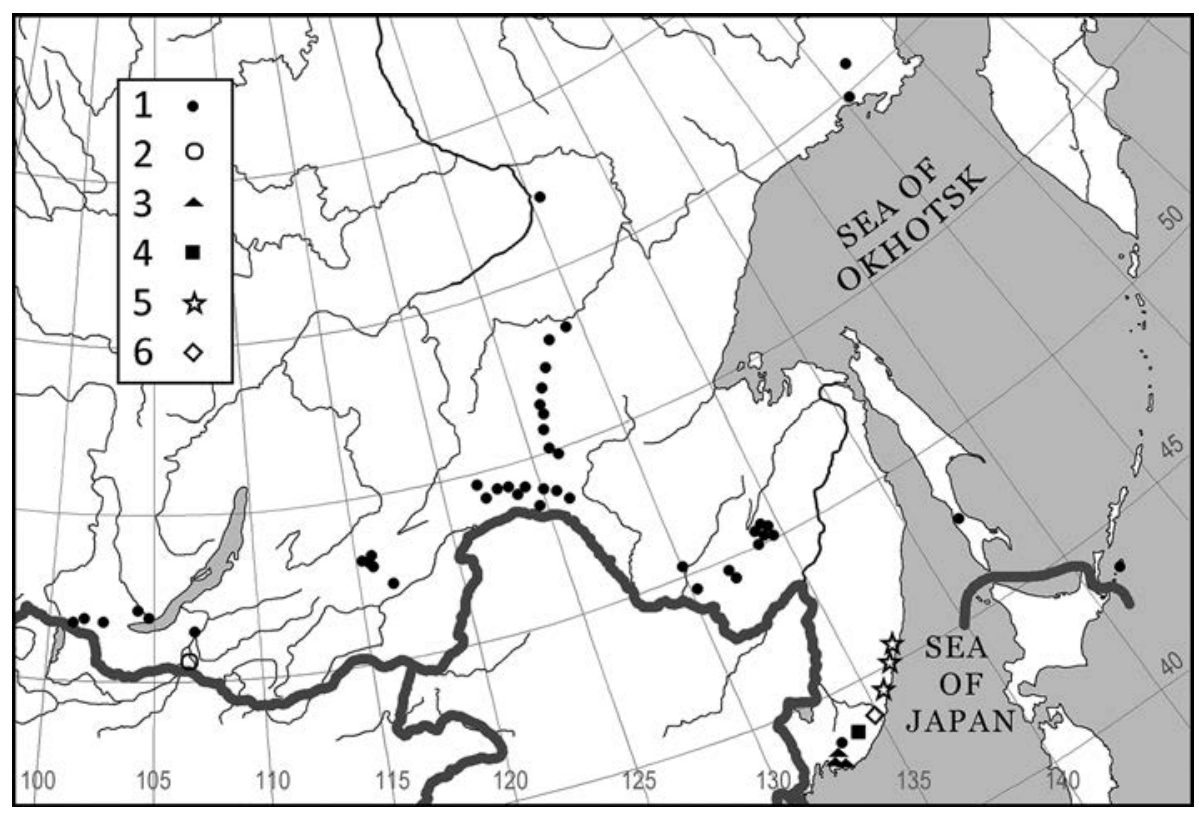

Figure 1 The scheme of specimen collections in the eastern part of Asian Russia: 1 - Dasiphora fruticosa, $2-D$. parvifolia, $3-D$. davurica, $4-D$. gorovoii, $5-D$. mandshurica, $6-D$. davurica var. flava

A chromatographic comparison of the aqueous ethanol extracts from the leaves revealed that the greatest number of phenolic components was present in D. fruticosa (33 compounds), and the lowest number in $D$. parvifolia and $D$. davurica var. flava (19 phenolic compounds; Table 1). Components 1, 2, 12, and 25 as well as hyperoside, isoquercitrin, ellagic acid and its glycoside, avicularin, quercitrin, astragalin, and quercetin were detected in all the species under study, whereas component 3 was not found only in D. gorovoii leaves. In D. fruticosa, $D$. davurica, and $D$. davurica var. flava, an extra component (number 4) was discovered, and in D. fruticosa, components 10, 17, and 18. In D. parvifolia, components 23, 26, and 31 were not detected. Rutin, kaempferol-3-O-rutinoside, and component 16 were not found in the samples of $D$. davurica var. flava and in leaves of $D$. gorovoii in contrast to the rest of the taxa. Components 19 and 20 were found only in D. fruticosa and D. gorovoii leaves; component 21 only in the leaves of D. fruticosa, D. gorovoii, and D. mandshurica; component 28 in D. fruticosa and D. mandshurica leaves; and component 33 in D. fruticosa and D. parvifolia leaves. Component 24 was not detected in either $D$. davurica var. flava leaves or D. davurica leaves, component 27 in the leaves of $D$. davurica var. flava, and component 30 in either D. parvifolia leaves or $D$. gorovoii leaves. Free kaempferol in trace amounts was detected in the leaves of D. fruticosa, D. davurica, and D. mandshurica. Free rhamnetin was not found in either $D$. fruticosa leaves or D. parvifolia leaves, and component 32 in either D. parvifolia samples or $D$. davurica var. flava samples (Table 1$)$.

On the basis of the chromatographic data, the coefficients of paired and group affinity (Ellison et al. 1962, Suresh \& Pandey 2003) were calculated next.

The highest similarity judging by 34 components $(86 \%)$ was observed between species $D$. davurica and D. mandshurica (Table 2). High paired affinity (76\%) was noted within two pairs of taxa: D. fruticosa-D. mandshurica and $D$. davuri$c a-D$. davurica var. flava. The other taxon pairs had a coeffi- cient of similarity less than $76 \%$. The lowest similarity in phenolic content (52\%) was observed between D. parvifolia and two taxa: D. gorovoii and D. davurica var. flava. Group affinity of the species was the lowest in D. parvifolia (489) and the highest in D. mandshurica (559). Thus, the closest relation was noted between $D$. mandshurica and $D$. davurica according to the coefficient of paired affinity for the concentrations of phenolic components (Table 2).

Analysis of individual phenolic compounds' concentrations in the leaves of all the analyzed plants also uncovered species specificity (Table 1). Thus, in D. fruticosa leaves, the dominant phenolic compounds were rutin, kaempferol-3O-rutinoside, components 3, 4, 10, 17, 18, 25, 30, and 33, whereas in D. parvifolia leaves, the dominant phenolic compounds were hyperoside, ellagic acid, and components 1, 2, and 12 (Table 1). D. davurica var. flava leaves accumulated substantial quantities of quercetin (up to $0.19 \mathrm{mg} / \mathrm{g}$ ), component $26(2.10 \mathrm{mg} / \mathrm{g})$, and component $31(1.16 \mathrm{mg} / \mathrm{g})$. In $D$. davurica, we detected high concentrations of kaempferol3-O-rutinoside and component $16(0.33$ and $0.48 \mathrm{mg} / \mathrm{g}$, respectively). In $D$. gorovoii leaves, the dominant phenolic compounds were isoquercitrin $(2.62 \mathrm{mg} / \mathrm{g})$, avicularin $(2.68 \mathrm{mg} / \mathrm{g})$, quercitrin $(1.93 \mathrm{mg} / \mathrm{g})$, quercetin $(0.19 \mathrm{mg} / \mathrm{g})$, and components 19-21, 23, 27, and 32 (Table 1). D. mandshurica was noteworthy because of high accumulation of astragalin $(0.49 \mathrm{mg} / \mathrm{g})$, kaempferol $(0.10 \mathrm{mg} / \mathrm{g})$, rhamnetin $(0.31 \mathrm{mg} / \mathrm{g})$, component $24(0.94 \mathrm{mg} / \mathrm{g})$ and component $28(1.60 \mathrm{mg} / \mathrm{g})$. A relatively high concentration of ellagic acid glycoside was detected in two species: D. fruticosa (9.00 mg/g) and D. davurica (9.47 mg/g; Table 1).

There were substantial differences in the total phenolic content of leaves among the analyzed taxa (Table 3). The highest accumulation of phenolic compounds in the leaves was observed in D. fruticosa $(27 \mathrm{mg} / \mathrm{g})$ and $D$. parvifolia (26 mg/g), and the lowest in D. mandshurica and D. davurica var. flava (14 mg/g each). It was found that in D. davurica and 
Table 1. The content of phenolic compounds in the leaves of Dasiphora species ( $\mathrm{mg} / \mathrm{g}$ of absolutely dry weight).

\begin{tabular}{|c|c|c|c|c|c|c|}
\hline Phenolic compounds & $\begin{array}{l}\text { D. fruticosa } \\
\text { (52 CPs) }\end{array}$ & $\begin{array}{l}\text { D. parvifolia } \\
\text { (1 CP) }\end{array}$ & $\begin{array}{l}\text { D. davurica } \\
\text { var. flava } \\
\text { (1 CP) }\end{array}$ & $\begin{array}{l}\text { D. davurica } \\
\text { (4 CPs) }\end{array}$ & $\begin{array}{l}\text { D. gorovoii } \\
\text { (1 CP) }\end{array}$ & $\begin{array}{l}\text { D. mandshurica } \\
\text { (3 CPs) }\end{array}$ \\
\hline Compound 1 & $0.64 \pm 0.42$ & $1.93 \pm 0.02$ & $0.37 \pm 0.00$ & $0.25 \pm 0.09$ & $0.33 \pm 0.00$ & $0.18 \pm 0.02$ \\
\hline Compound 2 & $1.72 \pm 1.06$ & $2.40 \pm 0.03$ & $0.19 \pm 0.00$ & $0.31 \pm 0.11$ & $0.43 \pm 0.00$ & $0.14 \pm 0.02$ \\
\hline Compound 3 & $0.87 \pm 0.56$ & $0.49 \pm 0.01$ & $0.11 \pm 0.00$ & $0.30 \pm 0.13$ & b.l. & $0.05 \pm 0.00$ \\
\hline Compound 4 & $0.30 \pm 0.07$ & b.l. & $0.15 \pm 0.00$ & $0.30 \pm 0.13$ & b.l. & b.l. \\
\hline Hyperoside & $2.04 \pm 1.22$ & $4.47 \pm 0.05$ & $0.90 \pm 0.01$ & $1.69 \pm 0.54$ & $1.20 \pm 0.01$ & $0.53 \pm 0.32$ \\
\hline Isoquercitrin & $2.30 \pm 1.06$ & $0.73 \pm 0.01$ & $1.01 \pm 0.01$ & $1.18 \pm 0.33$ & $2.62 \pm 0.03$ & $0.90 \pm 0.14$ \\
\hline Rutin & $0.34 \pm 0.20$ & $0.18 \pm 0.00$ & b.l. & $0.21 \pm 0.04$ & b.l. & $0.12 \pm 0.00$ \\
\hline Ellagic acid & $3.00 \pm 1.80$ & $7.10 \pm 0.08$ & $1.22 \pm 0.01$ & $3.01 \pm 0.84$ & $2.05 \pm 0.02$ & $0.46 \pm 0.15$ \\
\hline Ellagic acid glycoside & $9.00 \pm 4.12$ & $1.32 \pm 0.01$ & $0.63 \pm 0.01$ & $9.47 \pm 2.00$ & $0.15 \pm 0.00$ & $0.78 \pm 0.33$ \\
\hline Compound 10 & $0.86 \pm 0.43$ & b.l. & b.l. & b.l. & b.l. & b.l. \\
\hline Avicularin & $1.53 \pm 0.91$ & $1.66 \pm 0.02$ & $2.19 \pm 0.02$ & $0.84 \pm 0.14$ & $2.68 \pm 0.03$ & $2.32 \pm 1.29$ \\
\hline Compound 12 & $0.93 \pm 0.56$ & $2.36 \pm 0.03$ & $1.31 \pm 0.01$ & $0.77 \pm 0.13$ & $1.27 \pm 0.01$ & $0.73 \pm 0.15$ \\
\hline Quercitrin & $0.31 \pm 0.19$ & $0.46 \pm 0.01$ & $0.62 \pm 0.01$ & $0.49 \pm 0.29$ & $1.93 \pm 0.02$ & $0.33 \pm 0.02$ \\
\hline Astragalin & $0.32 \pm 0.20$ & $0.39 \pm 0.00$ & $0.08 \pm 0.00$ & $0.22 \pm 0.15$ & $0.22 \pm 0.00$ & $0.49 \pm 0.30$ \\
\hline Kaempferol-3-O-rutinoside & $0.33 \pm 0.19$ & $0.12 \pm 0.00$ & b.l. & $0.33 \pm 0.20$ & b.l. & $0.10 \pm 0.06$ \\
\hline Compound 16 & $0.23 \pm 0.08$ & $0.19 \pm 0.00$ & b.l. & $0.48 \pm 0.24$ & b.l. & $0.12 \pm 0.00$ \\
\hline Compound 17 & $0.25 \pm 0.13$ & b.l. & b.l. & b.l. & b.l. & b.l. \\
\hline Compound 18 & $0.21 \pm 0.09$ & b.l. & b.l. & b.l. & b.l. & b.l. \\
\hline Compound 19 & $0.18 \pm 0.09$ & b.l. & b.l. & b.l. & $0.25 \pm 0.00$ & b.l. \\
\hline Compound 20 & $0.22 \pm 0.08$ & b.l. & b.l. & b.l. & $0.34 \pm 0.00$ & b.l. \\
\hline Compound 21 & $0.39 \pm 0.23$ & b.l. & b.l. & b.l. & $0.74 \pm 0.01$ & $0.63 \pm 0.00$ \\
\hline Quercetin & $0.13 \pm 0.08$ & $0.14 \pm 0.00$ & $0.19 \pm 0.00$ & $0.12 \pm 0.03$ & $0.19 \pm 0.00$ & $0.12 \pm 0.06$ \\
\hline Compound 23 & $0.23 \pm 0.11$ & b.l. & $0.24 \pm 0.00$ & $0.16 \pm 0.01$ & $0.38 \pm 0.00$ & $0.19 \pm 0.04$ \\
\hline Compound 24 & $0.40 \pm 0.24$ & $0.16 \pm 0.00$ & b.l. & b.l. & $0.13 \pm 0.00$ & $0.94 \pm 0.01$ \\
\hline Compound 25 & $1.70 \pm 1.02$ & $1.39 \pm 0.02$ & $0.78 \pm 0.01$ & $0.33 \pm 0.06$ & $1.64 \pm 0.02$ & $1.57 \pm 0.94$ \\
\hline Compound 26 & $0.63 \pm 0.38$ & b.l. & $2.10 \pm 0.02$ & $0.20 \pm 0.09$ & $0.15 \pm 0.00$ & $0.39 \pm 0.14$ \\
\hline Compound 27 & $0.53 \pm 0.31$ & $0.53 \pm 0.01$ & b.l. & $0.33 \pm 0.15$ & $2.12 \pm 0.02$ & $1.63 \pm 0.68$ \\
\hline Compound 28 & $1.29 \pm 0.77$ & b.l. & b.l. & b.l. & b.l. & $1.60 \pm 0.00$ \\
\hline Kaempferol & $0.06 \pm 0.04$ & b.l. & b.l. & $0.06 \pm 0.00$ & b.l. & $0.10 \pm 0.03$ \\
\hline Compound 30 & $1.67 \pm 1.00$ & b.l. & $0.27 \pm 0.00$ & $0.19 \pm 0.08$ & b.l. & $0.42 \pm 0.08$ \\
\hline Compound 31 & $0.30 \pm 0.18$ & b.l. & $1.16 \pm 0.01$ & $0.18 \pm 0.07$ & $0.50 \pm 0.01$ & $1.00 \pm 0.13$ \\
\hline Compound 32 & $0.13 \pm 0.01$ & b.l. & b.l. & $0.15 \pm 0.00$ & $3.65 \pm 0.04$ & $0.13 \pm 0.01$ \\
\hline Compound 33 & $0.43 \pm 0.26$ & $0.36 \pm 0.00$ & b.l. & b.l. & b.l. & b.l. \\
\hline Rhamnetin & b.l. & b.l. & $0.23 \pm 0.00$ & $0.08 \pm 0.00$ & $0.18 \pm 0.00$ & $0.31 \pm 0.03$ \\
\hline Number of compounds & 33 & 19 & 19 & 25 & 22 & 27 \\
\hline
\end{tabular}

Notes: the data are presented as the mean value \pm standard deviation; $\mathrm{C} \geq 1.0 \mathrm{mg} / \mathrm{g}$ : the main component; $1.0 \leq \mathrm{C} \leq 0.1$ $\mathrm{mg} / \mathrm{g}$ : a minor component; $\mathrm{C} \leq 0.1 \mathrm{mg} / \mathrm{g}$ : trace amounts; b.l.: concentration below the detection limit $(0.01 \mathrm{mg} / \mathrm{g})$.

Table 2. Paired affinity (\%) and group affinity (GA [\%], last column) of Dasiphora species according to the profiles of phenolic compounds.

\begin{tabular}{|c|c|c|c|c|c|c|c|}
\hline Species & D. fruticosa & D. parvifolia & $\begin{array}{l}\text { D. davurica var. } \\
\text { flava }\end{array}$ & D. davurica & D. gorovoii & D. mandshurica & GA \\
\hline $\begin{array}{l}\text { D. fruticosa } \\
D . \text { parvifolia } \\
D . \text { davurica var. flava } \\
D . \text { davurica } \\
\text { D. gorovoii } \\
D . \text { mandshurica }\end{array}$ & 100 & $\begin{array}{l}58 \\
100\end{array}$ & $\begin{array}{l}53 \\
52 \\
100\end{array}$ & $\begin{array}{l}71 \\
63 \\
76 \\
100\end{array}$ & $\begin{array}{l}62 \\
52 \\
64 \\
62 \\
100\end{array}$ & $\begin{array}{l}76 \\
64 \\
64 \\
86 \\
69 \\
100\end{array}$ & $\begin{array}{l}520 \\
489 \\
509 \\
558 \\
509 \\
\mathbf{5 5 9}\end{array}$ \\
\hline
\end{tabular}

Table 3. The concentration of phenolic compounds (total and by groups) in the leaves of Dasiphora species (mg/g of absolutely dry weight).

\begin{tabular}{|c|c|c|c|c|c|c|}
\hline Phenolic compounds & D. fruticosa & D. parvifolia & $\begin{array}{l}\text { D. davurica var. } \\
\text { flava }\end{array}$ & D. davurica & D. gorovoii & D. mandshurica \\
\hline $\begin{array}{l}\text { Total content of } \\
\text { phenolic compounds }\end{array}$ & $27 \pm 7$ & $26 \pm 0.3$ & $14 \pm 0.2$ & $21 \pm 3$ & $23 \pm 0.3$ & $14 \pm 5$ \\
\hline $\begin{array}{l}\text { including glycosides: } \\
\text { quercetin } \\
\text { kaempferol } \\
\text { rhamnetin }\end{array}$ & $\begin{array}{l}13.2 \pm 4.5 \\
1.1 \pm 0.5 \\
2.9 \pm 1.7\end{array}$ & $\begin{array}{l}8.9 \pm 0.1 \\
1.5 \pm 0.0\end{array}$ & $\begin{array}{l}4.2 \pm 0.0 \\
0.1 \pm 0.0 \\
3.8 \pm 0.0\end{array}$ & $\begin{array}{l}7.4 \pm 1.2 \\
0.3 \pm 0.1 \\
0.4 \pm 0.3\end{array}$ & $\begin{array}{l}7.7 \pm 0.1 \\
0.3 \pm 0.0 \\
11.3 \pm 0.1\end{array}$ & $\begin{array}{l}3.3 \pm 1.8 \\
1.6 \pm 1.0 \\
3.8 \pm 1.3\end{array}$ \\
\hline Sum of flavonols & $17.0 \pm 5.2$ & $9.3 \pm 0.1$ & $8.6 \pm 0.1$ & $8.2 \pm 1.1$ & $19.7 \pm 0.2$ & $9.2 \pm 4.8$ \\
\hline Sum of tannins & $11.8 \pm 5.0$ & $8.4 \pm 0.1$ & $1.8 \pm 0.0$ & $12.5 \pm 2.7$ & $2.2 \pm 0.0$ & $1.2 \pm 0.3$ \\
\hline
\end{tabular}


D. gorovoii leaves, the total phenolic content was at an intermediate level (from 21 to $23 \mathrm{mg} / \mathrm{g}$ ).

In the plant leaves, the proportion of some flavonols in the total phenolic content varied from $34 \%$ to $85 \%$ among the taxa being studied. The highest concentration of flavonols was found in $D$. gorovoii leaves $(19.7 \mathrm{mg} / \mathrm{g})$, with the close second being $D$. fruticosa leaves $(17.0 \mathrm{mg} / \mathrm{g})$. The total content of flavonols in the leaves of three taxa $-D$. parvifolia, D. mandshurica and D. davurica var. flava, was virtually the same (9.3-8.6 mg/g, respectively). D. davurica leaves showed the lowest total flavonol content $(8.2 \mathrm{mg} / \mathrm{g}$; Table 3$)$.

Furthermore, among the studied taxa, there were differences in the aglycone profile of leaf extract hydrolysates. In the analysis of aglycones, which are generated by the acidic hydrolysis of glycosides, three compounds were detected: quercetin, kaempferol, and rhamnetin. They were identified virtually in all the taxa under study except for $D$. parvifolia, in which rhamnetin was not detectable (Table 4). Quercetin derivatives were dominant in $D$. davurica, D. parvifolia, and $D$. fruticosa leaves $(91 \%, 87 \%$, and $78 \%$, respectively), whereas rhamnetin derivatives were dominant in the samples of D. gorovoii and D. mandshurica (58 \% and $47 \%$ ). Meanwhile, it was noted that in $D$. gorovoii and D. mandshurica leaves, the proportion of quercetin derivatives was also high (40\% and $37 \%$, respectively). In D. mandshurica and D. parvifolia, kaempferol derivatives were present in considerable amounts $(17 \%$ and $13 \%$, respectively). The proportion of rhamnetin glycosides was high in the leaves of D. davurica var. flava (47\%) but low in D. davurica (only $5 \%$ ). It is worth noting that in $D$. gorovoii leaves, rhamnetin derivatives were dominant (58\%), thus confirming the similarity of $D$. gorovoii with $D$. mandshurica. On the other hand, in D. gorovoii leaves, the proportion of kaempferol derivatives was minimal (2\%), making this species similar to D. davurica. This finding may be a confirmation of the hybrid origin of $D$. gorovoii: from $D$. mandshurica and $D$. davurica. Thus, in the leaves, the differences in the profile of quercetin, kaempferol, and rhamnetin derivatives reflect interspecies differences among the plants under study.

To determine similarities in the aglycone content of leaf extract hydrolysates, cluster analysis of the plants by Ward's method was performed next. Euclidean distance was calculated as a measure of variation. In the dendrogram, the leaf samples of the studied species yielded two clusters (Fig. 2).

The first cluster included D. mandshurica, D. gorovoii, and $D$. davurica var. flava. The latter and D. gorovoii were found to be the closest species by aglycone content, and D. mandshurica was close to them. The second cluster included $D$. fruticosa and $D$. parvifolia, and $D$. davurica showed the least similarity with them. Perhaps the differences of these three species from the others are related to the high concentration of quercetin and relatively low concentration of rhamnetin in $D$. fruticosa and $D$. davurica or to the absence of rhamnetin (methylated quercetin) in $D$. parvifolia. In the two species and one variety in the first cluster (D. mandshurica, D. gorovoii, and D. davurica var. flava), a relatively high concentration of the methylated form (rhamnetin) was found. The presence of the methylated form is an indication of evolutionary species superiority (Bate-Smith 1976, Harborne 1977, Vysochina 2004).

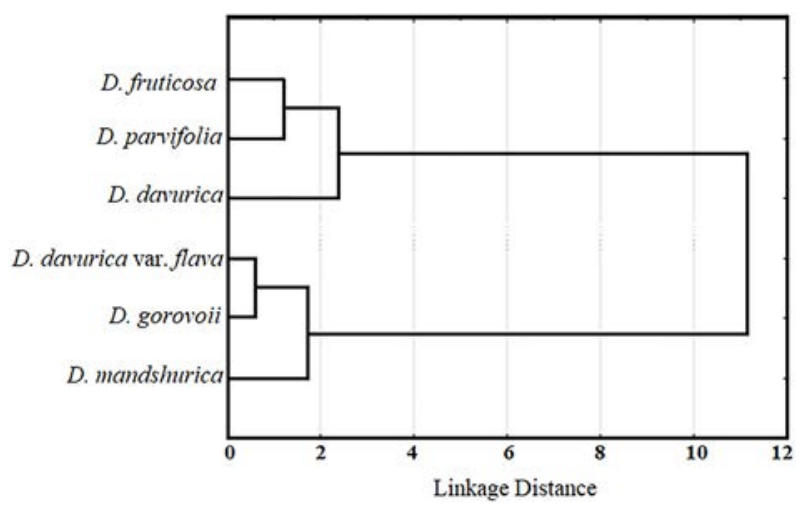

Figure 2 The dendrogram of Dasiphora species similarity in the aglycone content of leaf extract hydrolysates (Ward's method, Euclidian distances)

Table 4. The quercetin : kaempferol : rhamnetin ratio (\%) in the leaf extract hydrolysates from Dasiphora species.

\begin{tabular}{ll}
\hline Species & Ratio \\
\hline D. fruticosa & $78: 06: 16$ \\
D. parvifolia & $87: 13: 00$ \\
D. davurica var. flava & $51: 01: 47$ \\
D. davurica & $91: 04: 05$ \\
D. gorovoii & $40: 02: 58$ \\
D. mandshurica & $37: 17: 47$ \\
\hline
\end{tabular}

In addition, there were differences in the accumulation of ellagic compounds. The highest total ellagic content was found in $D$. davurica leaves $(12.5 \mathrm{mg} / \mathrm{g})$. Slightly lower total ellagic content was noted in the leaves of two species: D. fruticosa and D. parvifolia (11.8 and $8.4 \mathrm{mg} / \mathrm{g}$, respectively), whereas the lowest was detected in the samples of $D$. mandshurica, D. davurica var. flava, and D. gorovoii leaves (1.2, 1.8, and $2.2 \mathrm{mg} / \mathrm{g}$, respectively; Table 3). The analysis of individual ellagic compounds indicated that in $D$. fruticosa leaves, the content of ellagic acid $(3.0 \mathrm{mg} / \mathrm{g})$ was lower than that of ellagic acid glycoside $(9.0 \mathrm{mg} / \mathrm{g})$. In $D$. parvifolia, a different pattern was observed: dominance of ellagic acid among ellagic compounds $(7.1 \mathrm{mg} / \mathrm{g})$ and the opposite situation for its glycoside $(1.3 \mathrm{mg} / \mathrm{g})$. In $D$. davurica var. flava and $D$. gorovoii, ellagic acid content was higher (1.2 and $2.0 \mathrm{mg} / \mathrm{g})$ than the content of ellagic acid glycoside (0.6 and $0.2 \mathrm{mg} / \mathrm{g}$, respectively). On the contrary, in D. davurica (the highest total ellagic content) and in D. mandshurica (the lowest total ellagic content), the concentration of ellagic acid was the lowest among ellagic compounds (3.0 and $0.5 \mathrm{mg} / \mathrm{g}$ ), whereas the concentration of ellagic acid glycoside was the highest (9.5 and $0.8 \mathrm{mg} / \mathrm{g}$; Table 1 ).

\section{CONCLUSION}

The phenolic profiles of Dasiphora species show species specificity and may be used to determine taxonomic affiliation of the plants. The largest numbers of phenolic compounds were detected in $D$. davurica and $D$. mandshurica (25 and 24 compounds, respectively), and the lowest in $D$. parvifolia and $D$. davurica var. flava (19 compounds). The highest paired affinity in terms of the group of phenolic compounds was noted between D. mandshurica and D. davu- 
rica. The highest group affinity (in terms of concentrations of phenolic components in the taxa under study) was observed between $D$. mandshurica and $D$. davurica. The lowest group affinity was observed between two pairs of taxa: $D$. parvifolia-D. gorovoii and D. parvifolia-D. davurica var. flava.

In the leaves, the differences in the concentration and profile of phenolic compounds were also studied in detail among the plants. Each analyzed taxon was characterized by high accumulation of specific components: rutin and kaempferol-3-O-rutinoside in D. fruticosa; hyperoside and ellagic acid in D. parvifolia; quercetin in D. davurica var. flava; ellagic acid glycoside in $D$. davurica; isoquercitrin, avicularin, quercitrin, and quercetin in D. gorovoii; and astragalin, kaempferol, and rhamnetin in D. mandshurica. Species specificity turned out to be based on the aglycone structure of flavonol glycosides. In D. fruticosa, D. parvifolia, and D. davurica, there was high accumulation of quercetin glycosides, whereas in D. davurica var. flava, D. gorovoii, and D. mandshurica, there was high accumulation of the glycosides of rhamnetin. The highest content of phenolic compounds (total and by groups) was detected in D. parvifolia and D. gorovoii, and the highest total ellagic content in $D$. davurica.

\section{ACKNOWLEDGEMENTS}

The authors are grateful to Dr. P.V. Krestov for the help with the collection of all the species specimens of the genus Dasiphora in Primorsky and Khabarovsk Territories. We are greatly indebted to Drs. V.A. Bakalin and K.A. Korznikov for collecting the specimens of D. fruticosa in Magadan and Sakhalin regions. Besides, the authors are grateful to Ms. I.V. Andysheva and Mr. V.D. Vasilev for helping with field research in the Amur region and in the Sakha Republic (Yakutia). The English language was corrected and certified by shevchuk-editing.com.

\section{LITERATURE CITED}

Baikov, K.S. (ed.). 2012. Check-list of flora of Asian Russia: Vascular plants. Izd-vo SO RAN, Novosibirsk, 640 pp. (in Russian with English abstract). [Конспект флоры Азиатской России: Сосудистые растения. 2012 / поА реА. К.С. Байкова. Новосибирск: ИзА-во СО РАН. 640 с.].

Bate-Smith, E.C. 1961. Chromatography and taxonomy in the Rosaceae with special reference to Potentilla and Prunus. Journal of the Linnean Society of London, Botany 58(370): 39-54.

Bate-Smith, E.C. 1976. Chemistry and taxonomy of Ribes. Biochemical Systematic and Ecology 4(1):13-23.

Cherepanov, S.K. 1995. Vascular plants of Russia and the adjacent states (within the former USSR). Mir i Sem'ya, SaintPeterburg, 992 pp. (in Russian). [Черепанов С.К. 1995. Сосудистые растения России и сопредельных госуАарств (в пределах бывшего СССР). Санкт-Петербург: Мир и семья. 992 с.].

Ellison, W.L., R.E. Alston \& B.L. Turner 1962. Methods of presentation of crude biochemical data for systematic purposes with particular reference to the genus Babia (Compositae). American Journal of Botany 6(1):599-604.

Ermakov, A.I., V.V. Arasimovich, N.P. Yarosh, Yu.V. Peruanskii, G.A. Lukovnikova \& M.I. Ikonnikova 1987. Biochemical methods of research of plants. Agropromizdat, Leningrad, 430 рp. (in Russian). [Ермаков А.И., Ара- симович В.В., Ярош Н.П., Перуанский Ю.В., Ауковникова Г.А., Иконникова М.И. 1987. Методы биохимического исследования растений. Аенинград: АгропромизАат. 430 с.].

Harborne, J.B. 1977. Flavonoids and the evolution of the Angiosperms. Biochemical Systematic and Ecology 5(1):7-22.

Khramova, E.P. 2013. Chemotaxonomic study of Siberian species of Pentaphylloides Hill. Turczaninowia 16(4):55-62 (in Russian with English summary). [Храмова Е.П. 2013. Хемотаксономическое исследование сибирских виАов рода Pentaphylloides Hill // Turczaninowia. T. 16, № 4. C. 55-62].

Khramova, E.P. 2014. The content and composition of flavonoids Pentaphylloides fruticosa in natural conditions and the introduction. Himiya rastitel'nogo syr'ya 1:185-193 (in Russian with English summary). [Храмова Е.П. 2014. Состав и содержание флавонолов Pentaphylloides fruticosa в природе и культуре // Химия растительного сырья. № 1. С. 185-193].

Khramova, E.P. 2016. The genus Pentaphylloides Hill (Rosaceae) of Asian Russia (phenolic compounds, element composition in the nature and culture, a chemotaxonomy): Dis. ... Doct. Biol. Sciences. Novosibirsk, 437 pp. (in Russian). [Храмова Е.П. 2016. Род Pentaphylloides Hill (Rosaceae) Азиатской России (фенольные соединения, элементный состав в природе и культуре, хемотаксономия): Аис. ... А-ра. биом. наук. Новосибирск. 437 с.].

Khramova, E.P. \& N.M. Shkel' 1999. Ecological and biochemical peculiarities of Pentaphylloides fruticosa (L.) O. Schwarz under introduction. Sibirskii ekologicheskii zhurnal 6(3):237-244 (in Russian with English summary). [Храмова Е.П., Шкель Н.M. 1999. Экомого-биохимические особенности пятилистника кустарникового при интродукции // Сибирский экологический журнал. Т. 6, № 3. С. 237-244].

Khramova, E.P., N.V. Tsybulya \& L.N. Chindyaeva 2013. Antimicrobial activity of volatile compounds and content of phenolic components in some species of Pentaphylloides (Rosaceae). Rastitel'nye resursy 3(4):598-611 (in Russian with English summary). [Храмова Е.П., Цыбуля Н.B., Чиндяева А.Н. 2013. Антимикробная активность метучих соединений и содержание фенольных компонентов у некоторых видов рода Pentaphylloides (Rosaсеае) // Растительные ресурсы. Т. 3, № 4. С. 598-611].

IPNI. 2015. The International Plant Names Index. Available from: http://www.ipni.org/. Last accessed 20.05.2018.

Julkunen-Tiitto, R., M. Rousi, J. Bryant, S. Sorsa, M. Keinänen \& H. Sikanen 1996. Chemical diversity of several Betulaceae species: comparison of phenolics and terpenoids in northern birch stems. Trees 11:16-22.

Laitinen, M.-L. 2003. Variation in secondary chemistry within a natural population of birch: Effects of genotype, environment and ontogeny: PhD Dissertations in Biology, University of Joensuu, Finland, 98 pp.

Miliauskas, G., T.A. van Beek, E.J. Sudhölter, P.R. Venskutonis, J.P.H. Linssen \& P. De Waard 2004. Antioxidant activity of Potentilla fruticosa. Journal of the Science of Food and Agriculture 84(15):1997-2009.

Pshennikova, L.M. 2006. A new species of the genus Dasiphora (Rosaceae) from the Russian Far East. Botanicheskii Zhurnal 91(6):951-954 (in Russian with English summarу). [Пшенникова А.M. 2006. Новый вид рода Dasiphora (Rosaceae) с Аальнего Востока России // Ботанический журнал. Т. 91, № 6. С. 951-954]. 
Pshennikova, L.M. 2016. Achene morphology of the Far Eastern species of the genus Dasiphora Raf. (Rosaceae): systematic implications. Botanica Pacifica 5(1):63-68.

Rausher, M.D. 2006. The evolution of flavonoids and their genes. In: The Science of Flavonoids (E. Grotewold, ed.), pp. 175-212. Springer, Ohio, USA.

Robards, K. \& M. Antonovich 1997. Analytical chemistry of fruit bioflavonoids a review. The Analyst 122(2):11-34.

Sychyov, K.S. 2005. The methods of a high-performance liquid chromatography and a solid-phase extraction. OOO "Veda", Moscow, 165 pp. (in Russian). [Сычев К.С. 2005. Методы жиАкостной хроматографии и твердофазной экстракции. Москва: ООО “ВеАа”. 165 с.].

Suresh, N.B. \& V.S. Pandey 2003. Silica gel chromatographic study of phenolic compounds in some cultivated cucurbits. Himalayan Journal of Sciences 1(2):123-125.

Tril, V.M. 1977. Comparative analysis of phenolic compounds of the genus Potentilla L. Southeast Altai. In: Rastitel'nye resursy Yuzhnoi Sibiri iputi ib osvoeniya (K.A. Sobolevskaya, ed.), pp. 33-45, Nauka, Novosibirsk, (in Russian). [Триль B.M. 1977. Сравнительный анализ фенольных веществ рода Potentilla L. Юго-Восточного А^тая // Растительные ресурсы Южной Сибири и пути их освоения / под реА. К.А. Соболевской. Новосибирск: Наука. С. 33-45].
Van Beek, T.A. 2002. Chemical analysis of Ginkgo biloba leaves and extracts. Journal of chromatography A 967(1):21-35.

Vysochina, G.I. 2004. Phenolic compounds in the taxonomy and phylogeny of the buckwheat family. Nauka, Novosibirsk, 240 pр. (in Russian). [Высочина Г.И. 2004. Фенольные соединения в систематике и филогении семейства Гречишных. Новосибирск: Наука. 240 с.].

Williams, C.A., J.B. Harborne, J.R. Greenham, R.J. Grayer, G.C. Kite \& J. Eagles 2003. Variations in lipophilic and vacuolar flavonoids among European Pulicaria species. Phytochemistry 64(1):275-283.

Wink, M. 2003. Evolution of secondary metabolites from an ecological and molecular phylogenetic perspective. Phytochemistry 64(1):3-19.

Wolf, T. 1908. Monographia der Gatung Potentilla. In: Bibliografie der Botanik. XVI, Hf. 71 (T. Wolf, ed.), pp. 1-715, Stuttgart.

Yuriev, D.V., K.I. Eller \& A.P. Arzamastsev 2003. The analysis of flavonol glycosides in preparations and dietary supplement on the basis of Ginkgo biloba extract. Farmatsiya 52(2):7-10 (in Russian with English summary). [Юрьев А.В., Эмкер К.И., Арзамасцев А.П. 2003. Анализ флавонолгликозидов в препаратах и БАА на основе экстракта Ginkgo biloba / / Фармация. Т. 52, № 2. С. 7-10]. 